\title{
A. R. FAKHRUDDIN: THE FACE OF TASAWUF IN MUHAMMADIYAH
}

\author{
By: Masyitoh*
}

\begin{abstract}
With emphasizing to truth Islam and refusal to taqlid, bid'ah and churafat, Muhammadiyah has appreciation to Islamic mysticism (read: akhlaki Islamic mysticism). Although Islamic mysticism is more individual necessity and the term has never been mentioned, but many of Muhammadiyah figures practice Islamic mysticism individually. It was began from founder of Muhammadiyah, K.H. Ahmad Dahlan and others figures, such as: Ki Bagus Hadikusumo, K.H. Mas Mansyur, Buya Hamka, AR.Fakhruddin,etc. A.R Fakhruddin him self can be addressed as Kadda an yukuuna Suufiyan (near to be a Sufi), in this case Sufi Akhlaqi. It is caursed by all akhlakul karimah characteristics have already mixed up in his soul, such as: patient, thank God, Wara Zuhud, Qana'ah, Tawwakal, Ikhlas, Risha, etc. In the meantime, his spiritual life which fills more of his life and it is reflecting Islamic mysticism attitudes. A Sufi's live can be reflected from his attitude and thought about: taubat, taqarrub, dzikullah, khusyu', tawaddhu', khauf, raja, muraqobah, and istiqamah, these maqam are common to be done in Islamic mysticism world.
\end{abstract}

Keyword : Muhammadiyah, mysticism, Sufi Akhlaqi, Spiritual and maqam.

\section{A. Introduction}

The birth of Muhammadiyah movement in the early $20^{\text {th }}$ century, precisely on 8 Dzulhijjah $1330 \mathrm{H}$, or on $18^{\text {th }}$ of November 1912, at least, is because of the influence of tajdid movement (reformation, the renewal of Islamic thought) which was sparked by Muhammad Ibn 'Abd al-Wahab (1703-1792) in the Emirate Arab, Muhammad Abduh (1849-1905), Muhammad Rasyid Ridha (1865-1935) in Egypt, and soon. Each figure has special thought characteristic, different from one another. If Muhammad Ibn 'Abd al-Wahab focused on aqidah purity, so that his movement is more purification, then Muhammad Abduh focused more on the use of modern culture and took education way, therefore, his movement was more modernist and populist. 
Meanwhile, Muhammad Rasyid Ridha emphasized the important of relation to al-Quran texts as the frame of understanding Islam, which was known as al-Ruju' ila al-Qur'an wa al-Sunnah (return to al-Qur'an and al-Sunnah). Therefore, his movement is more textual, that later becomes the root of fundamentalism (alushuliyah) in the Middle East ${ }^{1}$. From the study of KH. Ahmad Dahlan, it is seen that how this founder of Muhammadiyah was being impressed and more or less influenced by those figures' thought in which then it was matched and contextualized to the Javanese social and cultural setting, Indonesian people in common. At that time, Indonesian community was in the condition of being colonized, left behind, move backward, poor and most of them tended to get TBC (Tahayul, Bid'ah and Churafat) decease.

As tajdid (renewal) movement, in understanding and implement the Islamic teaching, Muhammadiyah really develops the spirit of tajdid and ijtihad (use the rational thinking in solving and taking conclusion of several problems of law and other which are not found their argumentation explicitly in al-Qur'an and al-Sunnah, as well as move away from taklid (following the religious teaching blindly, without appropriate understanding to its argumentation), so that besides known as religious social movement this movement is also well known as tajdid movement.

The areas of ijtihad dan tajdid of Muhammadiyah, from the first time, are always focused on the historical problems of humanity which also touch the problems of nationality and community. The problem of raising poverty through education and health service is the concrete and authentic problem of community. This attitude and real action was done by the founder of Muhammadiyah in its early establishment and is still continuous until now, as this religious and humanistic ethic needs wider space and response from Muhammadiyah follower and others.

\footnotetext{
*the lecturer of FAI and Magister Studi Islam Universitas Muhammadiyah Jakart, and now hold the mandate as UMJ rector. E-mail: info@umj.co.id or masyitoh@umj.ac.id

1 Syafiq Syafiq A. Mughni, Muhammadiyah dan Pemikiran Keagamaan dalam Muhammadiyah Menyongsong Abad 21, (Yogyakarta: LPPI, LP3M, FAI, UMY, Pustaka Suara Muhammadiyah, 1998.), p. 17
} 
Muhammadiyah soul as tajdid movement actually is located in its fight with the problem of historical human variety. To revitalize and refresh the movement of religious thought renewal Muhammadiyah in the context of Muhammadiyah community, is by reexamine the meaning of texts normative (nash) of al-Qur'an and al-Sunnah more contextually, by relating and connecting them directly or contextualize them actually with the socio-historical problems of contemporary Islam variety $^{2}$.

As the pioneer of Islam renewal especially in Indonesia, with the characteristics of purification (purification of faith and worship) or rationalistic (in the field of muamalah duniawiyah), Muhammadiyah has contributed something very fundamental, which is its critical way to status quo of Islamic thought at its birth or on the way of nation life. Besides, the uniqueness of renewal characteristic brought by Muhammadiyah is located on its amaliyah side which emphasis on social obligation, such as building educational institution, hospital, orphan house, mosque and other dakwah facilities.

In the context of purification, al-Qur'an and al-Sunnah al-shahihah (valid) normatively is the prominent paradigm in the aqidah commitment or the implementation of ibadah mahdhah. From this textual normative paradigm, it was created the doctrine that something can only be believed and applied if there is command (al-Qur;an and al-Sunnah). While in the context of rationalization, alQur'an and al-Sunnah al-shahihah are still becoming the mean reference, however in the belief and application of this field muammalah duniawiyah there is a usage of ushul principles: al-ashl fi al-asyya al-ibahah (all problems of mu'amalah duniawiyah are permitted) as long as there is no prohibition or controversy with alQur'an and al-Sunnah.

As a renewal religious organization, Muhammadiyah really argues that the key of Moslem prosperous and progress is located on the mend of education. ibid., pp. 6-7.

${ }^{2}$ M. M. Amin Abdullah, "Muhammadiyah dan Pemikiran Keagamaan” in Syafiq A. Mughni, 
Therefore, from earlier the name of this organization was taken from a school name founded by Ahmad Dahlan one year before he established Muhammadiyah. ${ }^{3}$

This Muhammadiyah movement is well known widely as religious social movement which is founded to adapt Islam with modern situation of Indonesia, because this movement declares itself as renewal movement that care and concern with the development of Islam and Islam community, and causes revitalization of Moslem in Indonesia.

As the pioneer of Islamic thought renewal that gives priority to the rational aspect of religiosity (although nowadays is not as vocal and aggressive as before) and emphasizes the important of mind and the education of mind, in practice many the leaders and members show and focus on the important of spiritual life which is very close to tasawuf area. The life necessity to pure the soul (akhlak) which comes from religious teaching and the will to oblige all the commandment of Allah based on Allah book and Sunnah of the Prophet as well as "characterize themselves to Allah characteristics", are the characteristics of tasawuf life attitude. Even thought that kind of attitude was not known as tasawuf in the Prophet's life, because term or laqab (tittle) Sufi at that time was not exist. The term just emerged in the end of $2^{\text {nd }}$ century and the first of $3^{\text {rd }}$ century hijriyah. ${ }^{4}$ Ibn Timiyah $(661-718 \mathrm{H})$ points out that the expert of religious, knowledge and worship at that moment was known as salaf people, who are then called by shufiyah wa al-fuqara. ${ }^{5}$

The attitude and spiritual life of some Muhammadiyah leaders, are done as the application of effort to eliminate bid'ah, syirk and khurafat as well as sanctify the religious practice, such as religious practice model (read: tasawuf) of Ibn Taimiyah. Those who are included in this category (Sufi) are those who really obligate Allah and

\footnotetext{
${ }^{3}$ Djarnawi Hadikusumo, Matahari-Matahari Muhammadiyah (Yogyakarta, t.t), p. 72. that the first religious schools which used seat and black board are religious schools of Muhammadiyah built in 1911. see also Alwi Shihab, Membendung Arus,

${ }^{4}$ Abd. Al-Fattah Ahmad Fuad, Ibn Taimiyah Wa Mauqifuhu min al-Fikr al-Falsafah, (Kairo: 1980), pp. 234-235 234.

5 Ibn Taimiyah, al-Furqon baynAuliya al-Rahman Wa auliya al-Syaithan p. 70. D an lihat pula, Ibid., p
} 
some of them are still in the level of perfecting, they are called as ahl al-yamin. ${ }^{6}$ Meanwhile, Imam al-Ghazali $(1085-1111 \mathrm{M})$ gives the meaning of tasawuf: "the sincerity to Allah and good the social life with human being". Everybody who is sincere to Allah and improves their social life to all human being, in al-Ghazali's opinion, is $\mathrm{Sufi}{ }^{7}$

Meanwhile the sincerity to Allah SWT means to omit self needs (hawa alnafs) to do the commands of Allah with all of his heart. While a good social life with human means not to give priority to their own need upon other's need, as long as other's need is not on contrast to syariah. Because, those who are willing to the controversy of syariah or those who deny, al-Ghazali argues, they are not Sufi. Therefore, Sufi is people who take their way of life by doing the syariah appropriately and takes spirituality (hakikat) as well from syariat teaching and come closer continuously to Allah SWT. The attitude of obligation to syariat then being shown within fully morale attitude (great akhlak) in daylily life (tasawuf akhlaqi)

If the meaning of tasawuf refers to what have been explained by Ibn Taimiyah and al-Ghazali above, then in Muhammadiyah comes some faces of tasawuf, namely those who have intense obligation and spiritual life. It is not amazing if we take a deep attention to one of K.H.A. Dahlan's pupil's opinion, he is K.R.H. Hadjij, that among the Muhammadiyah founder's references are books written by some figures such as Ibn Taimiyah, Ibn al-Qayyim, Muhammad Ibn Abd Wahhab, Muhammad 'Abduh and including the works of al-Ghazali which are tasawuf books such as Ihya 'Ulum al-Din, Bidayah al-Hidayah, Kimiyah al-Sa'adah, Kitab al-'Arba'in fi Ushul al-Din and others that became K.H.A. Dahlan's reading, ${ }^{8}$ so that the close

\section{2.}

${ }^{6}$ Taqiyuddin Ibn Taimiyah, Tasawuf dan Kritik terhadap Filsafat Tasawuf, (Kairo, 1986), p.

${ }^{7}$ Al-Imam al-Ghazali, al-Qowaid al-Asyrah dari Majmu'ah al-Rasail, Juz 5 (Beirut, Dar alKutub al-Ilmiyyah, 1988), pp. 143-155.

8 Muh. Djazman al-Kindi, "Gagasan dan Fikiran Ahmad Dahlan dalam" Almanak Muhammadiyah 1416 H (Yogyakarta, Majlis Pustaka PP. Muhammadiyah, 1995), p. 210-211, see also Ahmad. Syafi'i Ma'arif, "Apa Literatur KHA. Dahlan” in Muhammadiyah, Sejarah, Pemikiran dan Amal Usaha, (Yogyakarta, Tiara Wacana, 1990), p. 25-30. 
relationship of spiritual life, which is very close to tasawuf area, also coloring the personality of the founder of this Islamic renewal movement. Even his next generation such as Ki Bagus Hadikusumo, who was intense in living this kind of life (read: tasawuf). He emphasized the important of great akhlak and simplicity of life. He was sympathy to the crisis of akhlak in the community. Many people admit as Moslem (their ID card is Islam), but their attitude is not Islamic. Toward this crisis, Ki Bagus wrote about akhlak in his book pustaka ihsan that talk about istiqamah, tawwakal, muhasabah, adl, shidq, tawadhu', ikhlas, amanah, shabr and qana'ah. ${ }^{9}$

Meanwhile the figure of A.R. Fakhruddin is also qualified to be included in the category as Sufi person in Muhammadiyah. Because on the writer' opinion, he he may represent the face of spiritual life in Muhammadiyah, based on some reasons. First, personal life practices of A.R. Fakhruddin shows a spiritual life that is very close to tasawuf. This might be seen, for instance, in the daily life, when he was on duty, in the neighborhood, society or even in the area of Muhammadiyah organization on his leading, he always reflected his personality mutasawwif and tasawuf characteristic which is akhlaqi, took priority the training and implementation of attitude which showed great akhlak.

His life represented the life and the life that was simple ascetic, not ngoyo (zahid). He always emphasizes on good akhlak. In one of his speech A.R. Fakhruddin, Nakamura had ever quoted extract of his speech as follows: ${ }^{10}$

"That we can pray five times a day regularly, however if our attitude/ akhlak is still bad, still greedy, mean, do not want to pay attention to the poor people, then our prayer will not be accepted by Allah, they will never enter the paradise, even into the hell. We can finish fasting, but if we still talk about others badness, lied, tricked, arrogant, then our fasting will have no use and not be accepted by Allah, let's us pray, fast and pilgrimage, pay zakat and above all of this let's us develop our akhlak".

\footnotetext{
${ }^{9}$ Farid Ma'ruf, Analisis Akhlak dalam Perkembangan Muhammadiyah, (Yogyakarta, Majlis Tabligh, PDM, 1990), pp. 24-31.

${ }^{10}$ Mitsuo Nakamura, Agama dan Lingkungan Kultural Indonesia (Surakarta, Hapsara, 1983), pp. $62-63$
} 
Later A.R. Fakhruddin adds:

" that the exact way to shape a great akhlak is by doing the worship, with a full awareness to the tauhid. The way that must be taken by full awareness is the willingness of someone to be ikhlas. Ikhlas shows to the mental orientation that entirely is not binded to duniawi circumstances, empty, clean, and this emptiness must be filled by Allah fully by worshiping to Allah, not to the other. That sunnah prayers, including witir, dhuha prayer and other are strongly recommended. And that dzikir, wirid, are not tarekat monopoly, and are allowed to be practiced if those may help the increasing somebody's piety as well as ikhlas in worshipping or interaction with human".

In his action and deed, A.R. Fakhruddin can be called representing the personality of "amal", the figure that emphasized on a real action, humanity social action. The priority for him is how Islam can really be applied in the daily life. The deep satisfaction is when Islam community can really represent themselves as good moslems, moslem in belief, in words and in action. ${ }^{11}$

Among Moslem characteristic of "amal" is nearer to tasawuf area, than Moslem "intellectual" that may closer to the area of kalam or philosophy.

Secondly, his writings, obviously told in different narrative compared to alGhazali's or Ibn Taimiyah's works, however the substances are similar to the tasawuf works of al-Ghazali, for example about adab-adab in having religion, al-Qawaid alAsyrah, obligation act, avoiding sin, the sins of body and soul that are related to Allah SWT and human, about tauhid, iman, self purification from stain, sin, maksiat, and so on.

${ }^{11}$ This spirit may be inspired by Muhammad Abduh who had ever had reflection, that when he is in Paris France, he saw Islam was implemented by the West in many aspect of life (the city of Paris in Abduh's memory was known as clean, beautiful, comfortable, safe, order and full of civilization); even though he did meet too many Islam people. In the other hand, while he was in Cairo Egypt, he met many Moslem, however the Islamic teaching was hardly found in the real attitude. So, what needs to be emphasized is al-amalah al-Islami (Islamic attitude/action). Therefore, Abduh argues that al-Islam al-Mahjub bi al-muslimin (Islam is left behind, declined, stupid poor, etc. because of the attitude of Islam people themselves who are not doing Islam teaching correctly). Then, what is declined is not Islam, but the followers of Islam themselves who do not understand and implement the teaching of Islam that has a vision of development. 
The style of his writing is simple, but interesting and easy to read. At glance, because of its simplicity, it seems like lack of theoretical foundation that may represent him as a figure of modernism movement in Islam; whereas, that is his strength. As, what have been said and written are the manifestation of the depth and implementation of Islam he believed as well depart from honesty and personal sincere, daily experience and actual religious and society problem he met. With his works in the form of tadzkirah (moral warning/ learning) and anecdotes, it can be shown there that his characteristics and personality is his works.

Third, A.R. Fakhruddin is the longest top leader in Muhammadiyah (chief center principal Muhammadiyah) along the history of its development, namely 22 years (19680-1990), while the founder of Muhammadiyah it self which is K.H. Ahmad Dahlan led Muhammadiyah for 11 years (1912-1923). Even before being elected as the chief of PP Muhammadiyah, A.R Fakhruddin had been leader for along time in district and region and for 30 years had been given duty by the board of executive of Muhammadiyah to impulse dakwah in the remote area of Southern Sumatera.

Therefore, A.R. Fakhruddin had a great chance to contribute life characteristic of tasawuf nuance in Muhammadiyah movement leadership and life. In that period, through his leadership in national level, there were many activities and meetings, in the level of national, region, district, branch or subsection which might be done intensively and fully. Even he often came to halaqah (religious teaching in limited forums) in the circle of Muhammadiyah big family such as woman communities, 'Aisyiyah, Nasyi'atul 'Aisyiyah, youth, intellectual, teachers and many other communities.

A.R Fakhruddin is the symbol and sign of Muhammadiyah leadership, he becomes type of Muhammadiyah personality development and central figure who resigns from pyramid top of organization sincerely and willingly. He has transformed into the trade mark of the neatest Islamic organization in Indonesia. All of this, directly or indirectly may influence within the life of organization. Supported by 
almost all of his works which most of them are directed to organization family readers, such as Pedoman Muballigh Muhammadiyah (Muhammadiyah Muballigh manual), Pedoman Anggota Muhammadiyah (Muhammadiyah member manual), Muhammadiyah Abad XV H (Muhamadiyah of XV century Hijriyah), kepribadian Muhammadiyah (Muhammadiyah personality), Pemimpin Muhammadiyah (Muhammadiayah leader), and other works in the form of question and answer, articles in the magazine of Suara Muhammadiyah and Suara Aisiyah, as well as papers delivered in many halaqah, upgrading, seminars for members, members of the boards, or Muhammadiyah candidates, all of them were effective in a quite long time and gave tasawuf touch from its personality in the soul and application of Muhammadiyah members.

Themes of Halaqah session, tabligh, religious teaching, lecture, khotbah, or his writing that were spread in the brochures and magazines of internal Muhammadiyah organization, did not chose the explicit theme of tasawuf, as other figures in Muhammadiyah, auch as Buya Hamka, but it was full with the teaching of akhlaq that close to tasawuf area, that is tasawuf akhlaqi. While Hamka works in tasawuf fields, are more universal and directed to variety of readers, his works including Tasawuf Moderen (Modern Tasawuf); Tasawuf, Perkembangan dan Pemurniannya (Tasawuf, its development and purification); Renungan Tasawuf (Tasawuf Reflection), Lembaga Budi (Mind Institution) and Falsafah Budi (Mind Philosophy).

Without mentioning the word tasawuf actually A.R. Fakhruddin has practiced and spread the teaching of tasawuf inclusively. Time he had during becoming top figure of Muhammadiyah, gave him wide opportunity to disseminate his thoughts/reflection and call within his organizational attitude of personal practice in implementing the teaching of Islam with tasawuf nuance. His soul and personality show personal reflection of Sufi in term of taubat, takwa, wara, raja, khauf, khusu', tawadhu'. Qana'ah, tawwakal, syukr, shabr, ridha, istiqamah, ikhlas and many other 
stages in going through the way of tasawuf such as Imam al-Qusyairiyah in his Risalah al-Qusyairiyah. $^{12}$

In the opinion of the writer, the spiritual life of A.R.Fakhruddin can be grouped into personality that lives based on enlightment and has tasawuf characteristics (tasawuf akhlaqi), and becomes one of top figures and leader in Muhammadiyah organization community who experiences and has Sufi spiritual life. However, the tentative assumption above need to be proven, is it right that the spiritual life of A.R. Fakhruddin really has tasawuf characteristics that close to the world of Sufi? Then, is this statement precise to be referred to A. R. Fakhruddin? Don't his works specifically talk about tasawuf even tough they are full with dimension and teaching of akhlak?

\section{B. Problems}

The discussion in this writing actually departs from a willing to get precise answer from the question: Is there, in the background of Muhammadiyah movement (through its figures), attitude of spiritual life that close to the area of tasawuf? This question emerges because so far Muhammadiyah movement is known as the pioneer of renewal movement of Islamic thought, which gives priority to rational aspects in taking the religion and emphasizes the important of mind and mind education, in compare to the spiritual life which depends on the sensitivity of heart and intuition.

Therefore, this writing tries to present the answer from some questions that bother the writer and likely the readers, as follows:

1. To what extend and in what limitation is the spiritual life of A.R. Fakhruddin in his daily life so that it is assumed to close the area of tasawuf?

2. And if it is true, what tasawuf school is familiar to A.R.Fakhruddin?

3. Does A. R. Fakhruddin also discuss his reflection and thought in the form of writings that have akhlak and tasawuf characteristics?

\footnotetext{
${ }^{12}$ Abu al-Qasim Abd al-Karim al-Qusyairi, al-Risalah al-Qusyairiyah fi Ilm al-Tashawwuf, (Beirut, Dar al- Khair, t.t), p. 171.
} 
4. How is the influence of spiritual life attitude of A.R.Fakhruddin in the circle of his community that is in Muhammadiyah spectrum?

This writing is hoped to prove that in the background of the biggest modern organization movement of the world, borrowing Nurcholis Majid term, Muhammadiyah who notabene names himself as reformist organization and renewal movement, his figures, especially A.R.Fakhruddin, played spiritual life that intense and familiar with the life of tasawuf. Data and resource expected for this writing are from observation and interview with family and colleague and others and several writings of A.R. Fakhruddin itself and relevant writings of other figures, and with qualitative approach.

\section{Discussion}

1. He was Grown by and Developing Muhammadiyah

From his childhood A.R.Fakhruddin was undergone and grown in the circle of Muhammadiyah. Even it may be said that his life had unified to Muhammadiyah. His spirit to continuously learn was never end, although with an autonomous learning, or by taking the knowledge from Muhammadiyah figures or those who are popular as al-Sabiqun al-Awwalun such as KH.Sudja, KH. Ahmad Badawi, KRH. Hadjid, KH. Muchtar, Ki Bagus Hadikusumo, KH. Djohar, KH.Muslim, KH. Kanad, KH. Bakir Saleh, KH. Basyir Mahfydz, Hj. Badilah Zuber and so on. ${ }^{13}$

Those figures above are the people who forge A.R.Fakhruddin in the circumstance of religiosity and all about Muhammadiyah. They all are considered as parents by A.R.Fakhruddin. Therefore, whatever asked and commanded by them in implementing the knowledge and spreading the religion was done by A.R. Fakhruddin. Bring the mission everywhere, based on the command from his senior

${ }^{13}$ Suratmin, Perikehidupan, Pengabdian dan Pemikiran Abdur Razzaq Fakhruddin dalam Muhammadiyah, (Yogyakarta, Pustaka SM, 2000), p. 5. 
was done happily. This is the reason that later enlarges his name in the circle of Muhammadiyah.

The biography of A.R. Fakhruddin's career in Muhammadiyah was started from grass root, which was becoming the chief of subsection, branch, district, region to the centre leader. He could be the leader in the national level after going through very long process. His leadership for 22 years was not short, and this brought his name to the top of popularity, not only in the circle of Muhammadiyah, but also in the national stage and Indonesian society. His success in doing religious proselytizing and lead Muhammadiyah, was admitted by many people, in the circle of Muhammadiyah itself, in Moslem circle or even in the circle of non-Moslem.

It is fine to be said that A.R. Fakhruddin is the asset of Indonesia. All of this time was given to enlarge Muhammadiyah. To become a good leader, in accordance to A.R. Fakhruddin is the leader who experiences how the life of community in the real life, how the suffer and poor society in the low level and how the difficulty of doing religious proselytizing and moving the organization in the level of subsection which is very far from the city, that lack of media and facilities. All of the pain, difficulties, and ups and downs of somebody working in the basis level may give precious experience and create someone to be wiser in taking the policy and lead the community. ${ }^{14}$

A.R. Fakhruddin had obsession to continuously traind the leaders and leader candidates as well as doing the cadres, so that Muhammadiyah later delivers and has leaders who understand about Islam, fully comprehend Islamic teaching, understand basic and ambition of Muhammadiyah, comprehend and understand the suffering and dhu'afa people (those who are weak and powerless). A.R. Fakhruddin wished for Muhammadiyah leaders who have great attitude, wise, and skilful in taking every decision, tawadhu' in every steps and actions, simple in life, friendly and close to the people when facing people from any classes they are from. A.R. Fakhruddin had

${ }^{14}$ Suara Muhammadiyah, Pikiran dan Tindakan Pak AR (Yogyakarta, Pustaka SM, 1995), p. 6. 
ambision that Muhammadiyah leaders are those who has wide sight, see further ahead, creative in solving every problems, dynamic and innovative as what has been given by Rosulullah SAW as the example.A.R. Fakhruddin obsession was not redundant, because all of them had been given example from him. He is the example of life characteristic of Muhammadiyah who is sincere and restless.

Haedar Nashir in one of his writing in Suara Muhammadiyah says that association may turn and change, the earth and sun may gonjang-ganjing (in disarray), formal Muhammadiyah leader may change one thousand and one times, but A.R.Fakhruddin is still has Muhammadiyah with sincere and uncomplicated. Everybody is invited to reach easiness, and never difficult something easy. He did bring Muhammadiyah with frighten, fierce, glum and frown face. ${ }^{15}$

From this attitude A.R Fakhruddin developed Muhammadiyah. Nobody can deny and must admit that the existence of A.R. Fakhruddin in the top position of the association at that time had non small contribution in supporting the mutual understanding among Moslem community, between Moslem and government. The type of his straight, clean and pure leadership is beneficial modal in finding solution for the community problems. Type and his fresh jokes were able to melt the tension in the forum he attended. This type of leadership is really needed in the situation where the suspicious often becomes reason to take an action for those who have power.

\section{His Works and Dedication}

As a leader who has many ups and downs experiences in Muhammadiyah, A.R. Fakhruddin was responsible to always think about the effort to preserve, increase, and develop this very big organization in Indonesia. For this reason and for his submission to Allah SWT., he delivered his knowledge through his works in the form of books, monographs, essay compilations, or question and answers which later

15 Haedar Nashir, "Welas Asih dan Gembira dalam Muhammadiyah" dalam Suara Muhammadiyah (16-30 April, 1995), p.12. 
compiled by his students, or by A.R. Fakhruddin himself. His thought in common is categorizes into three main problems, namely religious problem, organizational problem and society problem. These problems are unified. Among his thought and works can be seen for example:

1. Memelihara Ruh Muhammadiyah (maintaining the soul of Muhammadiyah), published in 1996

This book is collection of his short writings, that contains about: development of religious social worship and social community, tabligh Muhammadiyah id tabligh Islam, purification of niat (will), messages for university students, do not fight to be a leader, soul of musyawarah in Muhammadiyah, worship based on guide from Rosulullah, and so on.

In one of his writing which is: Yang Berhak Memimpin Muhammadiyah (who has right to lead Muhammadiyah), the writer emphases on the great akhlak of Islam, take example from Rosulullah. The leader must be able to be example and uswatun hasanah for their follower especially in praying with fully sincere just to Allah, doing taqarrub to Allah with khusyu', tawadhu' and with the feeling of khasyyah (afraid of Allah Greatness) and taqwallah, and so on. This is the morale recommendation that has Sufistik nuance from his writing.

2. Muhammadiyah Abad XV Hijriyah (Muhammadiyah in the XV century of Hijriyah), published in 1985

This book consists of series of short discourse that at first entitled Muhammadiyah Tujuh Puluh Langkah Ke Depan (Muhammadiyah seventy steps forwards), a brochure prepared as a guide for people and leaders of Muhammadiyah that full of moral messages. The writer asks and emphases all the member and board of Muhammadiyah to have great akhlak, noble character. What is meant by this noble character is such as friendly if interact with others, not hurt somebody's heart when speak, like to help other people, never tell and dishonest, never envy and betrayal, never mean but defending the suppressed, all of them are noble characters. The main 
noble character in his opinion is the belief of the existence of Allah, believe that Allah is the Most Powerful, the One, the Knower, the Wiser, and the Perfect. Therefore, the source of noble characters is the submission to Allah, oblige His command and avoid His prohibition. A.R.Fakhruddin saw that between the belief and akhlakul karimah is going side by side.

3. Soal Jawab yang Ringan Ringan (simple answer and questions), published in 1990

This book is the answer to fulfill the demand from many circle of the society in the program of "Soal Jawab"(question answer) broadcasted in RRI Nusantara II Yogykarta, that was done by A.R.Fakhruddin together with Muchlas Abrar from religious affair of regional office of Daerah Istimewa Yogyakarta. The compilation of this question and answer contains problems of aqidah, akhlak, ibadah and muamalah, muamalah to Allah or to the human being. The interesting part of this book is that when A.R. Fakhruddin explained about kitab al-Adzkar, he suggested to memorize some particular prays, and reciting the sentence la Ilaha illa Allah one hundred times and subhanallah one hundred times as Prophet hadis he quoted as follows: "who recite la Ilaha illa Allah one hundred times, equal to free ten slavers. For him is noted (got) one hundred goodness, being forgiven of his one hundred faults and it becomes a fort from the Satan's temptation within that day until afternoon. And nobody who gains that specialty except for those who read more that that." 16

A.R. Fakhruddin quoted Prophet SAW's hadis as what had been delivered by Bukhari Muslim from Abu Hurairah, that Rosulullah SAW. Said: "Who recites subhanallah wa bi hamdihi one hundred times in a day, then his fault will be forgiven although its number is as many as froth of waves."17

Dzikir, wirid and doa that followed by a certain amount is really often recommended by A.R. Fakhruddin, as long as that dzikir and wirid help the doer to

\footnotetext{
${ }^{16}$ A.R. Fahruddin, Soal Jawab yang Ringan-Ringan (Yogyakarta, t.p, 1990), p. 22.

${ }^{17}$ Ibid.
} 
get soul calmness and peaceful mind. In this case, Allah says: "Varily, in the remembrance of Allah do hearts find rest.”(QS. Al-Ra'd \{13\}28) A.R.Fakhruddin really realized the human limitation and weakness, if only he or she does not rely on The Creator, through dzikir and begging for His help, then he or she may easily get into hopeless, and even his/her actions are far from sincerity. Isn't that each time a Moslem does the pray he always declares and commits to only worship and ask for Allah's help (QS. Al-Fathihah \{1\}5)?

Dzikir, wirid, or pray which are recommended by A.R. Fakhruddin as what he wrote in the chapter of kitab al-Adzkar that commonly based on verses of al-Qur'an and Hadis, among his writing that quoted by the writer are as follows:

1. As narrated by al-Bukhari and Muslim from Abu Hurairah, that Rosulullah SAW said: "two sentences that are light to be said, but have very heavy weight in scale in hereafter" are.....

2. From Tsauban r.a. said that Rosulullah SAW. After finish doing five prayers then $\mathrm{He}$ recited istighfar (asking for forgiveness) three times, then $\mathrm{He}$ recited....

3. From Mughirah ibn Syu'bah r.a. relly Rasulullah SAW. After finish praying then recited....

4. From Abu Sa'id al-Khudri said, Rsulullah SAW. Said: "the saying speech is the saying of.....

5. From Sahabat Anas r.a. said: the most do'a recited by Rosulullah SAW. Is...

6. From Abu Hurairah r.a. said, Rosulullah said:

"Allah, improve for me my religion that becomes the source of all my problems.

And improve my world that becomes the source of my life. And improve my hereafter that becomes the place for my return. Make my life journey as the addition for my goodness. And make my death as the release from all crimes."

This book also contains some pantun (traditional poetry) tittles, which talk about akhlak, syukr, tawadhu', shidq, ikhlas, ridha, and pantun of death, ukhuwah Islamiyah and other pantun that have tasawuf and khlak nuances. Examining this 
book, A.R. Fakhruddin also emphasized on some certain amounts for dzikir, wirid and prays the usual thing which is done in the world of tasawuf and tarekat. Off course the goal is obvious as what he said that as long as helping the doer to gat calmness souls and peaceful mind, why not?

Beside three books mention above, there are many more books that can not be discussed in this short paper. Even from a trustable source, there are still many writing of him that are spread anywhere, which can not be compiled until now. His works are full of moral and akhlak messages. Therefore, it strengthens the assumption of the writer that A.R. Fakhruddin can really be categorized into a zahid (who live simply), mukhlish (worship and work sincerely) and these close to the area of Sufi akhlaqi.

\section{The Essential of Performing Tasawuf}

Dimension of akhlak on A.R Fakhruddin personality that includes praised characteristics that is a chain of heart action and sometimes is called maqam (station) and ahwal (spiritual condition, in tasawuf, seems to be a special characteristic of A.R. Fakhruddin. Between akhlak and tasawuf (read: tasawuf practice/ spiritual life), actually is not so different. The basic difference of those two terms is likely to be formulated as follows:

1. That tasawuf practice/spiritual intelligence has a set of methodology which may likely to the development of akhlak

2. The principles of akhlak are more static, while method of sayr wa suluk (going through spiritual way) is dynamic.

3. In the study of akhlak, human soul is seen mlore as a place that must be beautified with decoration of noble akhlak, such as shabr, syukr, honest, and so on, then in the eyes of Sufi community, human soul is seen as living organism that grow to the maturity through spiritual journey.

4. Soul decoration in the view of akhlak, can be done randomly and really disorder, for example it can be started by generous character and so on, then 
in tasawuf, maqamat that must be taken stage by stage and continuously as well as well structured, for instance from maqam taubat to next maqam in which each maqam passed until the end of spiritual journey.

5. The knowledge of akhlak manages more on the relationship and responsibility between human and himself, with nature and with the God, then in tasawuf for the first stage is focused more on the relationship between human and God. This is because tasawuf believes that the relationship between human and God is the most central of source akhlak. ${ }^{18}$

Therefore, the writer views that someone's spirituality or spiritual intelligence is established because he/she focus him/herself more on the relationsheim between him/her with God. If we borrow the term of Junaid (a figure of Sufi who is considered as far stricter than Ibn Taimiyah), according to him tasawuf or spiritual life is: "You with Allah without any medium”. Furthermore, the essential of tasawuf in accordance to Junaid is that we always remember or together with Allah whenever and wherever.

To be always together with Allah, then it needs spiritual training that expected to take aexample of Allah's akhlak, this is in line with what has been said by Rosulullah ASW.: "have characters with the character/ akhlak of Allah". Therefore, if someone really has had good relationship with God, it means straight believe and istiqomah, then automatically he/she will have the example of good deeds of God and from here the good character to human will emerge.

A.R. Fakhruddin as a person whose life close to the spiritual life of Sufi is a figure that gives really most of his life to humanization, as the way to worship to Allah. This can be seen for instance in his daily life, when he was on duty or when he was in his family, in the society or in the middle of Muhammadiyah community. He always represented the personality of mutasawwif. His soul and personality reflected

${ }^{18}$ Disarikan dari Tasawuf Tanpa Tarekat, karya Ramli Bihar Anwar, 2002, p. 3-13, dan Tasawuf Antara Agama dan Filsafat oleh Ibrahim Hilal dan Majmu Fatawa, Kitab Ilm al-Suluk Oleh Ibn Taimiyah. 
personality with excellence spiritual intelligence such as in: taubat, taqarrub, taqwa, dzikir, khusyu', tawadhu', khauf, raja', muraqabah and istiqamah in ittiba' (follow with the right knowledge foundation) Rasul's sunnah. Philosophy and way of life of A.R. Fakhruddin can be grouped into character that live based on enlightment and tasawuf character. In the circle of Sufi figures several maqam or manzilah mentioned above are maqam or manzilah included within tasawuf akhlaqi.

Meanwhile, the writer sees that several maqam: taubat, taqarrub, taqwa, dizkr, khusyu', tawadhu', khauf, raja', muraqabah and istiqamah tend to precisely be grouped into spiritual attitude, because however A. R. Fakhruddin focused himself to the relationship with God. This relationship is continuous and still regarded as the most central source of akhlak that later creates noble attitude and deserve to be taken as example.

\section{Conclusion}

From the explanation above, the writer needs to make concluding notes as epilogue as follows:

1. A.R. Fakhruddin is a top figure leader of Muhammadiyah who always emphasized and applied the attitude of al-akhlaq al-karimah in every of his speech, action and deed. Dimension of akhlak which becomes trade mark or belong to A.R. Fakhruddin is characteristic such as: shabr, syukr, wara', zuhd, qana'ah, tawwakal, ikhlas, ridha, and so on. This characteristics are very dominant reflected in him through the attitude of his daily life, along with his command to spread Islam amar makruf and nahi mungkar that followed by akhlak of Rosulullah SAW. Meanwhile, spiritual life that imprinted most of the life of A.R. Fakhruddin that reflected the sttitude of akhlak tasawuf and life of a Sufi is represented in his attitude and thought about taubat, taqarrub (come closer) to Allah, taqwa, dzikrullah, khusyu', tawadhu', khauf, raja' muraqabbah and istiqamah. From the spiritual life he went through or that he implemented as mention above, actually A.R. Fakhruddin had come close to the area of tasawuf. 
If he can not be categorized as a Sufi (because the meaning of Sufi commonly accepted as those who have attitude of tasawuf akhlaqi and philosophy), then this figure of A.R.Fakhruddin can be called as: .......... (Almost close to tasawuf or close to the ittle of Sufi). And if this term is correct, then the writer places this figure in the position of "Sufi Akhlaqi".

2. Life practice of A.R. Fakhruddin which reflected attitude of akhlak and tasawuf, has dimensions of social, harakah and spreading Islamic mission. In every of his dakwah (spread Islamic mission), written or spoken is reflected the expression of life story and his actions that were very concerned to the community, nation and state. His invitation to always consistent and istiqamah and still be guided by kitabullah and Sunnah Rosul and bring them to real harakah (movement). Therefore, the core of Muhammadiyah as movement (harakah) organization, ja'iyah and association, that based on tauhid which becomes source and basic of Muhammadiyah life. A.R. Fakhruddin is a Muhammadiyah figure/ Islamic figure that deserved to be example in the case of "akhlak al-karimah"

3. A.R. Fakhruddin reflection and thought which are put in the form of writing, do not really take explicit theme about tasawuf like other figure in Muhammadiyah such as Buya Hamka or others, however his writings are full of akhlak teaching that very close to the area of tasawuf, in this case is tasawuf akhlaqi. Without mentioning the word tasawuf, actually he had practiced and spread examples of tasawuf akhlak and attitude inclusively. The time he has during being the top leader of Muhammadiyah, gave him quite wide chance to socialize his thought/ reflection and invitations in the organization or personal practice in implementing Islamic teaching that showed akhlak and tasawuf nuances. His soul and personality show personal mirror od a Sufi (read: Sufi akhlaqi) in wara', zuhd, taqwa and other several stages to go through the way of Sufi.

4. The spiritual life of A.R. Fakhruddin can be grouped into personality that lives based on enlightment and has tasawuf characteristic (tasawuf akhlaqi), and become one of top figures and leaders in the community of Muhammadiyah 
association that comprehended fully and spirited by Sufi akhlaqi. By this character, directly or indirectly, may affect the association life. Supported also with quite long time and his writing that mostly directed to association family readers, all of them are effective in giving the touch of "akhlak tasawuf" from his personal light in the soul and application of the Muhammadiyah members.

\section{BIBLIOGRAPHY}

Abdullah, M. Amin. "Muhammadiyah dan Pemikiran Keagamaan, dalam Muhammadiyah Menyongsong Abad 21.

Al-Gazzaali. 1998. al-Qawaid al-Asyrah dari Majmu’ah al-Rasail, Beirut: Dar alKutub al-Ilmiyah.

Al-Hujwiri. 1974. Kasyf al-Mahjub, Kairo: Dar al-Turats.

Ali, Mukti. 1985. Interpretasi Amalan Muhammadiyah, Jakarta, Harapan Melati.

Al-Kindi, Muh. Djazman. 1995. Gagasan dan Fikiran Ahmad Dahlan dalam Almanak Muhammadiyah, Yogyakarta: Majelis Pustaka PP. Muhammadiyah.

al-Qusyairi, Abu al-Qasim Abd al-Karim. al-Risalah al-Qusyairiyah Fi Ilm alTashawwuf, Beirut: Dar al-Khair.

al-Syirbashi, Ahmad. 1970. Rasyid Ridha Shahib al-Manar, Cairo.

Fakhruddin, A.R. 1982. Mikul Dhuwur Mendem Jero, Yogyakarta. 1983. Pancasila Kabeberaken, Agama Islam Kawedharaken, Yogyakarta. . 1985. Muballigh Muhammadiyah, Yogyakarta. 1985. Muhammadiyah Abad XV Hijriyah, Yogyakarta. 1985. Tiga Puluh Pedoman Anggota Muhammadiyah, Yogyakarta. . 1989. Muhammadiyah Menjelang Muktamar ke-42 di Yogyakarta, Yogyakarta. 1990. Pak AR Menjawab, Yogyakarta. 1990. Selamat Tahun Baru, Yogyakarta. . 1990. Soal Jawab Entheng-Enthengan, Yogyakarta. . 1990. Soal Jawab yang Ringan-Ringan, Yogyakarta. . 1992. Tuntunan Shalat Menurut Cara Rasulullah Saw, Yogyakarta. . 1994. Menyongsong sidang Tanwir Muhammadiyah di Solo, Yogyakarta: t.p. 
. 1995. Mengenang Pak AR, Yogyakarta.

. 1995. Pedoman Anggota Muhammadiyah, Yogyakarta.

1996. Memelihara Ruh Muhammadiyah, Yogyakarta.

. Abad XV Hijriah, Abad Kerukunan dan Kemajuan, Yogyakarta.

. Muhammadiyah adalah Organisasi Dakwah Islamiyah, Yogyakarta.

. Muhammadiyah, Halal Bi Halal dan Keprihatinan, Yogyakarta.

. Peringatan Maulid Nabi Besar Muhammad Saw, Yogyakarta.

. Pilihlah Pimpinan Muhammadiyah yang Tepat, Yogyakarta.

Fu'ad, Abd. Al-Fattah Ahmad. 1980. Ibn Taimiyah wa Mauqifuhu min al-Fikr alFalsafati, Cairo.

Hadjid, Kiyai. 1968. Ajaran KHA. Dahlan dengan 17 Kelompok Ayat-ayat al-Quran.

Kahin, Nationalism and Revolution in Indonesia.

Kusumo, Djarnawi Hadi. Matahari-Matahari Muhammadiyah, Yogyakarta: Persatuan.

Ma'arif, A. Syafi'i. 1996. Dinamika Pemikiran Islam dan Muhammadiyah, Yogyakarta: Pustaka Pelajar Offset.

- 1990. Apa Literatur KHA. Dahlan dalam Muhammadiyah, Sejarah, Pemikiran dan Amal Usaha, Yogyakarta: Tiara Wacana.

Ma'ruf, Farid. 1990. Analisis Akhlak Dalam Perkembangan Muhammadiyah, Yogyakarta: Majlis Tabligh, PDM.

Mughni, Syafiq A. 1998. Muhammadiyah dan Pemikiran Keagamaan dalam Muhammadiyah Menyonsong Abad 21, Yogyakarta : LPPI, LPM, FAI UMY, Pustaka Suara Muhammadiyah.

Mulkhan, Abdul Munir. 2003. Dari Semar ke Sufi : Kesalehan Multikultural sebagai Solusi Islam di Tengah Tragedi Keagamaan Umat Manusia, Yogyakarta: alGiyats.

Nakamura, Mitsuo. 1983. Agama dan Lingkungan Kultural Indonesia, Surakarta: Hapsara.

Peacock, James L. 1986. Gerakan Muhammadiyah Memurnikan Ajaran Islam di Indonesia, Jakarta: Cipta Kreatif.

Rais, M. Amin. 1995. Moralitas Politik Muhammadiyah, Yogyakarta: Dinamika.

Shihab, Alwi. 1997. Islam Inklusif, Bandung: Mizan. 
. 1998. Membendung Arus, Respons Gerakan Muhammadiyah Terhadap Penetrasi Misi Kristen di Indonesia, Bandung: Mizan.

Smith, Margareth. 2001. Mistikus Islam, Surabaya: Risalah Gusti.

Suratmin. 2000. Perikehidupan, Pengabdian dan Pemikiran AR. Fakhruddin dalam Muhammadiyah, Yogyakarta: Pustaka.

Taimiyah, Ibn. al-Furqon Bayn Auliya al-Rahman wa Auliya al-Syaithan. . 1986. Tasawuf dan Kritik terhadap Filsafat, Terjemahan.

Tobroni. 2005. The Spiritual Leadership: Pengefektifan Organisasi, Noble Industry Melalui Prinsip-prinsip Spritual Etis, Malang: UMM Press. 